\title{
TRAINING LOAD IMPACT ON RECOVERY STATUS IN PROFESSIONAL VOLLEYBALL ATHLETES
}

IMPACTO DA CARGA DE TREINAMENTO NO ESTADO DERECUPERAÇÃO EM ATLETAS PROFISSIONAIS DE VOLEIBOL

IMPACTO DELACARGA DEENTRENAMIENTO EN EL ESTADO DERECUPERACIÓN DEATLETAS PROFESIONALESDEVÓLEIBOL
Original Article

Artigo Original Artículo Original

\begin{abstract}
Thiago Andrade Goulart Horta' ( (Physical Education Professional) Pedro Henrique Prazeres de Lima'(iD (Physical Education Professional) Guilherme Garcia Matta' (ID) (Physical Education Professional) Jefferson Verbena de Freitas' (D) (Physical Education Professional) Bernardo Miloski Dias' (ID) (Physical Education Professional) Jeferson Macedo Vianna² (D) (Physical Education Professional) Heglison Custodio Toledo² (D) (Physical Education Professional) Renato Miranda' (ID) (Physical Education Professional) Thiago Ferreira Timoteo' (DD) (Physiotherapist)

Maurício Gattás Bara Filho' (D)
\end{abstract} (Physical Education Professional)

1. Universidade Federal de Juiz de Fora, Faculdade de Educação Física e Desporto, Training load control study group, Juiz de Fora, MG, Brazil.

2. Universidade Federal de Juiz de Fora, Faculdade de Educação Física e Desporto, Juiz de Fora, MG, Brazil.

\section{Correspondence:}

Thiago Andrade Goulart Horta. Faculdade de Educação Física e Desporto, Núcleo de Pesquisa sobre Controle da Carga de Treinamento. Rua José Lourenço Kelmer, s/n, Campus Universitário São Pedro, Juiz de Fora, MG, Brazil. 36036-900.

thiagogoulart198@yahoo.com.br

\begin{abstract}
Introduction: The success of training depends on the balance between training load magnitude and recovery. Objective: Verify the effect of training load distribution on recovery status, vigor and fatigue in volleyball players during a season. Methods: Nine male athletes from a professional volleyball team participated in the study. During 19 weeks of the season, quantification of the training load was performed through the session rating of perceived exertion (RPE) method, evaluation of the athletes'recovery status through the Total Quality Recovery (TQR) scale, and evaluation of the profile of mood state through the POMS questionnaire, with research focus for the subscales vigor and fatigue. Results: The average total weekly training load (TWTL) was $3206 \pm 685.5$ A.Us and the average recovery of the whole season was $15.3 \pm 0.57$. The mean values of fatigue and vigor were $11 \pm 3.05$ and $19.4 \pm 2.84$, respectively. Significant differences were found for the variables RPE, fatigue and Energy Index (Vigor - Fatigue) in the three different periods of the season (Preparatory Period, Competitive Period I and Competitive Period II). Conclusion: It was concluded that the training load and recovery monitoring methods used throughout the season were effective in controlling the variables, with a positive impact of training loads verified on the recovery values presented by the athletes. Level of Evidence III; Diagnostic study.
\end{abstract}

Keywords: Volleyball; Training; Recovery.

\section{RESUMO}

Introdução: O sucesso do treinamento depende do equilíbrio entre a magnitude da carga de treinamento e a recuperação. Objetivo: Verificar o efeito da distribuição das cargas de treinamento no estado de recuperação, vigor e fadiga, em jogadores de voleibol ao longo de uma temporada. Métodos: Participaram do estudo nove atletas do sexo masculino de uma equipe profissional de voleibol. Durante 19 semanas da temporada, realizou-se a quantificação da carga de treinamento através do método da Percepção Subjetiva do Esforço da sessão (PSE), da avaliação do estado de recuperação dos atletas através da escala da Qualidade Total de Recuperação (TQR), além da avaliação do perfil do estado de humor através do questionário POMS, com foco de investigação para as subescalas vigor e fadiga. Resultados: A carga de treinamento semanal total (CTST) média foi de $3206 \pm 685,5$ U.A. e a recuperação média de toda a temporada foi de 15,3 $\pm 0,57$. Já os valores médios da fadiga e vigor foram $11 \pm 3,05$ e 19,4 2,84, respectivamente. Diferenças significativas foram encontradas para as variáveis PSE, fadiga e Energy Index (Vigor - Fadiga) nos três diferentes períodos da temporada (Período Preparatório, Período Competitivo I e Período Competitivo II). Conclusão: Conclui-se que os métodos de monitoramento da carga de treinamento e recuperação utilizados ao longo da temporada foram eficazes no controle das variáveis, observando-se um impacto positivo das cargas de treinamento verificado nos valores de recuperação apresentados pelos atletas. Nível de evidência III; Estudo Diagnóstico.

Descritores: Voleibol; Treinamento; Recuperação.

\section{RESUMEN}

Introducción: El éxito del entrenamiento depende del equilibrio entre la magnitud de la carga de entrenamiento y la recuperación. Objetivo: Verificar el efecto de la distribución de las cargas de entrenamiento en el estado de recuperación, vigor y fatiga, en jugadores de vóleibol a lo largo de una temporada. Métodos: Participaron en el estudio nueve atletas del sexo masculino de un equipo profesional de vóleibol. Durante 19 semanas de la temporada, se realizó la cuantificación de la carga de entrenamiento a través del método de Percepción Subjetiva del Esfuerzo de Sesión (PSE), de la evaluación del estado de recuperación de los atletas a través de la escala de la Calidad Total de Recuperación (TQR), además de la evaluación del perfil del estado de humor a través del cuestionario POMS, con enfoque de investigación para las subescalas vigor y fatiga. Resultados: La carga de entrenamiento semanal total (CEST) promedio fue de 3206 $\pm 685,5$ U.A. y la recuperación promedio de toda la temporada fue de 15,3 \pm 0,57. Los valores promedio de fatiga y vigor fueron $11 \pm 3,05$ y 19,4 22,84, respectivamente. Se encontraron diferencias significativas para las variables PSE, fatiga y Energy Index (Vigor-Fatiga) en los tres diferentes perío dos de la temporada (Período Preparatorio, Período Competitivo ly Período Competitivo II). Conclusión: Se concluye que los métodos de monitorización de la carga de entrenamiento y recuperación utilizados a lo largo de la temporada fueron eficaces en el control de las variables, observándose un impacto positivo de las cargas de entrenamiento verificado en los valores de recuperación presentados por los atletas. Nivel de evidencia III; Estudio diagnóstico.

Descriptores: Voleibol; Entrenamiento; Recuperación. 


\section{INTRODUCTION}

In the context of elite Brazilian volleyball, teams develop seasons ranging from 32 to 40 weeks, including the preparatory period, state and national competitions, with little time for preparation until the start of the first official competitions. ${ }^{12}$ These particularities of the competitive calendar make the training planning and organization process even more complex, especially due to the short preparation time and the need to maintain athletes' performance for several weeks., ${ }^{3,4}$ The success of training, in turn, depends on the balance between training load magnitude and recovery. ${ }^{1,5-7}$

In recent decades, the session rating of perceived exertion (RPE) method ${ }^{8,9}$ has proved to be a simple and very useful tool for quantifying and monitoring volleyball training loads, ${ }^{1,25,10-14}$ indicating good applicability of the method in elite volleyball teams. The RPE represents a subjective parameter of measurement after the exercise session that reflects the integration between the central and peripheral signals, with a repercussion on efferent neural impulses from the motor cortex, generated and memorized in the central nervous system, interpreted by the sensory cortex, producing a general or local perception of the effort required to accomplish a particular task. Thus, the RPE represents a complex individual psychophysiological process related to genetic and environmental factors., 915

On the other hand, it is equally important to monitor athletes'recovery status in response to training loads in order to minimize negative adaptations by adjusting the loads or extending periods of rest, when necessary. ${ }^{7} 16$ For this purpose, the Total Quality Recovery (TQR) scale is a tool designed for simple application, allowing the daily monitoring of athletes' recovery, ${ }^{16}$ with recent studies demonstrating its effectiveness in elite volleyball teams. ${ }^{1,5,13}$ Another extremely valuable tool used to monitor athletes' recovery status is the Profile of Mood States (POMS) analysis questionnaire, enabling the quantification of psychological (changes in mood, depression, anxiety) and physical (fatigue, vigor, tiredness, etc.) indicators, which when combined can detect overtraining in athletes. ${ }^{17}$ The use of psychological criteria/markers in the assessment of recovery is relevant as some mood states have been reported to be highly sensitive to changes in training loads. ${ }^{13,16,18,19}$

Recent studies in the field of training load monitoring emphasize the validity, reliability, and practicality of using subjective methods of training load and recovery analysis. ${ }^{8,20,21}$ Accordingly, the aim of this study is to verify the effect of training load distribution on recovery status, vigor and fatigue in volleyball players throughout an entire season.

\section{MATERIALS AND METHODS}

The sample consisted of nine male athletes from a professional volleyball team in the state of Minas Gerais, Brazil. At the beginning of the season these athletes were aged $26.4 \pm 4.0$ years, with body mass $93.9 \pm 5.7 \mathrm{~kg}$, height $198.9 \pm 9.1 \mathrm{~cm}$ and body fat $7.2 \pm 1.7 \%$. All athletes had been participating in official competitions for at least five years. The study was approved by the Institutional Review Board (Human Research) of the Universidade Federal de Juiz de Fora under opinion No. 771,758, and all subjects signed an Informed Consent Form expressing their voluntary participation.

Data were collected over 19 weeks of training that made up a regular season. Throughout the season, the team took part in three competitions at state and national level: Campeonato Mineiro Adulto, Jogos do Interior de Minas Gerais, and Superliga de Vôlei, the latter representing the most important competition in the national scenario. Monitoring of training load and recovery status took place daily before and after sessions, respectively. The training was planned and applied by the technical committee and was not influenced by the researchers. The season was divided into three blocks: Preparatory Period (week 1 to 8), Competitive Period I (week 9 to 14) and Competitive Period II (week 15 to 19).
The athletes were presented with the RPE scale for the session ${ }^{9}$ on a daily basis, 30 minutes after the end of each training session, and answered the question:"How did your training go?"They were introduced to the tool in question and instructed to refer to the training session as a whole when answering the questions. The training load (TL) of the session was calculated by the product between training intensity, measured by the 10-point RPE scale, and the total session time in minutes, generating a value in arbitrary units (A.U.). For each week the total weekly training load (TWTL), which is the sum of the loads of all training sessions of the week, was calculated.

Prior to the start of the first training session of the day, athletes answered the question "How do you feel about your recovery?"using the Total Quality Recovery (TQR) scale proposed by Kenttä and Hassmén. ${ }^{16}$ The answer is given by indicating a score in the TQR table, which ranges from six to 20 , where the lowest value represents the worst recovery status, and the highest value the best recovery status. In this study, the mean TQR was obtained based on the mean daily values of each week throughout the season.

\section{Profile of Mood States - POMS}

Composed of 65 items with closed questions, the POMS questionnaire enables us to quantitatively evaluate six transient mood states: tension, depression, anger, vigor, fatigue and mental confusion. Each item is analyzed according to a likert scale (5 points). Specifically, the questionnaire was applied at the beginning of each training week (Monday). We only collected data from the vigor and fatigue subscales (15 questions) due to the length of the questionnaire. ${ }^{17}$ The above subscales were used to calculate (in the three training blocks of the season), the energy index of the athletes presented by Kenttä et al., ${ }^{22}$ which is obtained from the result of the Vigor subscale minus the Fatigue subscale, and represents an indicator of the subjective energy status of the athlete.

\section{Statistical analysis}

Data were expressed as mean and SD. The assumption of normality was assessed with the Shapiro-Wilk test while sphericity of the data was assessed using the Mauchly test. TWTL,TQR, RPE, Vigor and Fatigue were compared between the training blocks using repeated measures ANOVA with Bonferroni correction. To verify the correlation between TWTL and TQR, RPE, Vigor and Fatigue, we used Pearson's correlation. Data were analyzed using SPSS v. 20 (SPSS ${ }^{\circledR}$ Inc, Chicago, IL) software, considering a significance level of $p<0.05$.

\section{RESULTS}

A description of the weeks of the season analyzed in terms of the number of games, competitions, and trips made by the team is presented in Table 1. It can be seen that the competition calendar of elite volleyball teams entails a stressful schedule of travel, practice and games. During the period analyzed, the team competed in a total of 30 games, including preparatory and official matches, with an average load of 1.5 games per week, and spent a few weeks playing in official games involving up to two trips to different locations.

The total weekly training load (TWTL) and the total quality recovery (TQR) scale values of the 19 weeks are described in Figure 1. Throughout the season, mean TWTL and recovery values were 3,206 $\pm 685.5 \mathrm{~A}$.U and $15.3 \pm 0.57$, respectively. The lowest TWTL value of the season was 1,892 A.U (week 11) while the highest was 4,682 A.U (week 9). The recovery values ranged from 14.1 (week 5) to 16.2 (week 14).

Figure 2 contains a description of the TWTL and the fatigue and vigor statuses of the 19 weeks of training. Throughout the season, the mean values of Fatigue and Vigor were $11 \pm 3.05$ and $19.4 \pm 2.84$, respectively. The lowest Fatigue value of the season was 7.1 (week 18) and the highest was 18.0 (week 5). Vigor values ranged between 12.4 (week 5) and 24.4 (week 1). 
Comparing the different training periods of the season, it can be seen that Fatigue was significantly higher in the Preparatory and Competitive I periods, while the RPE was significantly higher in the Competitive I period compared to Competitive II. The Energy Index (Vigor - Fatigue) was significantly lower in the Competitive I period compared to the Competitive II period. There was no different in recovery and TWTL, as described in Table 2.

No correlations were found between TWTL and TQR $(p=0.38 ; p=$ $0.55 ; p=-0.320)$, TWTL and Vigor Status ( $p=-0.24 ; p=0.19 ; p=-0.39)$, TWTL and Fatigue Status ( $p=0.53 ; p=-0.068 ; p=0.062$ ), respectively in the Preparatory, Competitive I and Competitive II periods.

Table 1. Description of the routine of games, trips and competitions in the weeks of the season analyzed.

\begin{tabular}{c|c|c|c|c|c|c|c|c|c|c}
\hline Weeks & W1 & W2 & W3 & W4 & W5 & W6 & W7 & W8 & W9 & W10 \\
\hline Games & --- & 1 & 1 & --- & 5 & 3 & 2 & 2 & --- & 1 \\
\hline Trips & --- & --- & 1 & --- & 2 & 2 & --- & --- & --- & 1 \\
\hline Competition & --- & F.G & S.C & --- & S.C+J.I & S.C+J.I & S.C & S.C & --- & J.I \\
\hline Period & PP & PP & PP & PP & PP & PP & PP & PP & PC1 & PC1 \\
\hline Weeks & S11 & S12 & S13 & S14 & S15 & S16 & S17 & S18 & S19 & \\
\hline Games & 4 & 2 & --- & 1 & 2 & 1 & 2 & 1 & 2 & \\
\hline Trips & 1 & --- & --- & --- & --- & 2 & 2 & -- & 1 & \\
\hline Competition & J.I & F.G & --- & S.L & S.L & S.L & S.L & S.L & S.L & \\
\hline Period & PC1 & PC1 & PC1 & PC1 & PC2 & PC2 & PC2 & PC2 & PC2 & \\
\hline
\end{tabular}

$\mathrm{F} . \mathrm{G}=$ friendly game; $\mathrm{S} . \mathrm{C}=$ state championship; $\mathrm{J} . \mathrm{I}=$ small town games; $\mathrm{S} . \mathrm{L}=$ super league; $\mathrm{PP}=$ preparatory period $\mathrm{PC1}=$ preparatory period $1 ; \mathrm{PC2}=$ preparatory period 2.

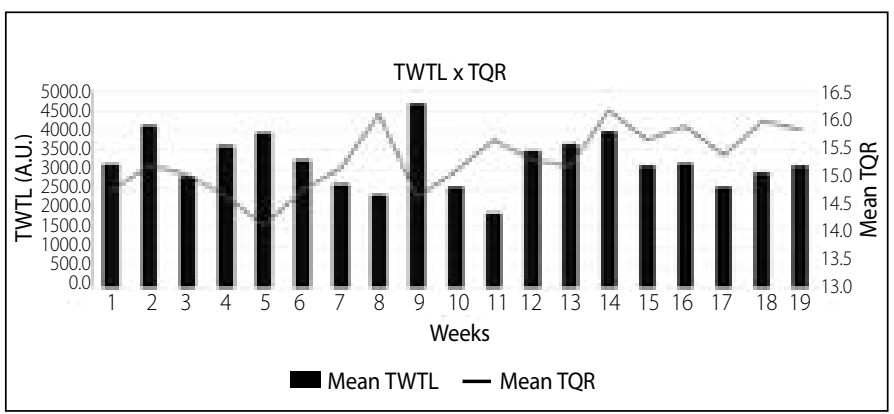

Figure 1. Description of total weekly training load and recovery status during the 19 weeks of the season.

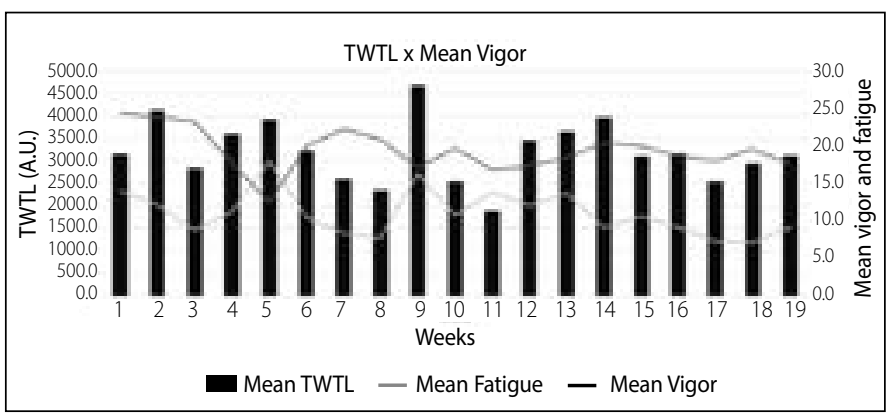

Figure 2. Description of the total weekly training load and recovery status during the 19 weeks of the season.

Table 2. Analysis of the variables Vigor, Fatigue, TQR, RPE, TWTL, Energy Index and number of games during the Preparatory, Competitive I and Competitive II periods.

\begin{tabular}{c|c|c|c}
\hline Variables & Preparatory & Competitive I & Competitive II \\
\hline Vigor & $20.62 \pm 3.96$ & $18.31 \pm 4.62$ & $18.76 \pm 3.74$ \\
\hline Fatigue & $11.82 \pm 2.76^{*}$ & $12.89 \pm 2.73^{*}$ & $8.65 \pm 2.65$ \\
\hline TQR & $14.95 \pm 0.79$ & $15.33 \pm 0.94$ & $15.74 \pm 1.01$ \\
\hline RPE & $4.14 \pm 0.50$ & $4.41 \pm 0.62^{*}$ & $3.86 \pm 0.50$ \\
\hline TWTL & $3228.44 \pm 521.96$ & $3369.44 \pm 605.33$ & $2973.22 \pm 727.23$ \\
\hline Energy Index & $8.79 \pm 5.79$ & $5.42 \pm 5.74^{*}$ & $10.11 \pm 4.96$ \\
\hline No. of games & 9 & 8 & 9 \\
*Difference for Competitive $\|$ period. & &
\end{tabular}

The correlation between RPE and TWTL in the Preparatory period was positive and very strong $(r=0.94 ; p<0.001 ; n=9)$, with a coefficient of determination of $88 \%$. In the Competitive I period, it was positive and very strong $(r=0.95 ; p<0.001 ; n=9)$, with a coefficient of determination of $90 \%$. In the Competitive II period, the correlation between RPE and TWTL was positive and very strong $(r=0.85 ; p<0.001 ; n=9)$ with a coefficient of determination of $72 \%$ (Hopkins et al., 2009). ${ }^{23}$

\section{DISCUSSION}

This study aimed to verify the effect of training load distribution on recovery status, vigor and fatigue in volleyball players during a season. It has been shown that the competitive schedule of professional volleyball teams in Brazil as well as in other sports in the country is extremely hectic. In our study, the team that was analyzed participated in three official competitions, two of which occurred at certain times in simultaneous periods. Such a scenario demands very careful planning of training and recovery sessions, which must be combined with the logistics of travel, matches and opponents. Kelly and Coutts, ${ }^{24}$ in a study with players of team sports, demonstrated that factors such as stronger opponents with away matches that require traveling over long distances and few days of training, directly influence the distribution of training loads, since the three variables already entail considerable stress for athletes. This context described above can be seen in Table 1 , at weeks 5, 6, 16, 17 and 19. On the other hand, games against teams with less competitive advantage and more similar team performance, financial and structural resources, represent direct confrontations in search of a better ranking in competitions, meaning that these key matches represent an even more incisive preparation in terms of training and recovery approaches within the team's periodization. Horta et al., ${ }^{25}$ in a study with a professional volleyball team, and Manzi et al., ${ }^{26}$ investigating a professional basketball team, demonstrated that training loads in weeks without games tend to be higher compared to weeks with two games.

The results found showed a wave pattern for both TWTL and recovery, Vigor and Fatigue, between the weeks of the season, clearly observed in Figures 1 and 2. In addition, the athletes maintained their recovery status within adequate limits, with a mean value of $15.3 \pm$ 0.57 throughout the season, which represents, according to the TQR scale, a "well recovered" recovery status. A similar TQR value was presented by Debien et al., ${ }^{1}$ while investigating training load monitoring in professional volleyball athletes, with a mean recovery status of 15.02 \pm 0.71 over a 36 -week season.

Analyzing the behavior of the TWTL in the Preparatory, Competitive I and Competitive II periods, no significant differences were found with this variable. Similar values were observed in the three training blocks, with a mean value throughout the season of 3,206 \pm 685.5 A.U. In other studies with volleyball athletes, 1,11,2 values between 3,000 and almost 6,000 A.U. of total weekly training load were demonstrated over longer monitoring periods. However, Freitas et al. ${ }_{1}{ }^{12}$ in a study with adult athletes competing in the National Volleyball League, observed a mean value of 1,790.9 A.U. over 22 weeks of preparation. Unlike the results presented, other studies showed differences in training load values between the different periods of the volleyball season., ${ }^{1,2,12}$

Regarding the recovery status of athletes obtained through the TQR, no significant differences were found between the three periods analyzed. A different result was presented by Debien et al. ' with volleyball athletes, where significant differences for recovery through TQR and training load were identified in different periods of the season. Corroborating this behavior, other studies have also attested to the effectiveness of TQR in detecting variations in recovery in response to increases and decreases 
in volleyball training loads. ${ }^{27,28} \mathrm{It}$ is important to emphasize that TQR may not respond exclusively to training loads, but is also influenced by other factors such as sleep quality, food and travel. ${ }^{29,30}$ Moreover, Nogueira et al. ${ }^{31}$ noticed that the presence of matches directly influenced the sleep quality, stress levels and mood of professional volleyball athletes in a competitive period. The management of the different variables involved in the process is complex, and the balance between training load and recovery is suggested in the literature as a key factor for positive training adaptations.,32

In the analysis of the Vigor and Fatigue indices obtained through the POMS questionnaire, it was observed that vigor did not undergo a significant change over the three periods analyzed, yet fatigue experienced a statistically significant decrease in the competitive period II in comparison to the values presented in the two previous blocks. Aoki et al., ${ }^{33}$ in a training load monitoring study with volleyball athletes from the under-16 and under-19 categories, found no significant differences for the overall POMS scale and subscales, including vigor and fatigue, between the preparatory and competitive periods totaling 9 weeks of training, although significant decreases in training load were observed between the above periods. Similar results were demonstrated by Arruda et al. ${ }^{19}$ with female players from the Brazilian basketball team, with no significant difference found for the POMS global scale and subscales over 40 days of preparation for an international competition.

One of the main findings of this study was the practicality and effectiveness of the training load monitoring and control method used, which allowed the technical committee to successfully adjust the work carried out during the period under analysis according to the demands of the team's competition calendar, observed through the results presented. Furthermore, the instruments used in the study to monitor training load and recovery rates demonstrated practicality in the adjustment of the routine set for the professional volleyball team, which in various situations during the competitive season conducts its training schedule away from their usual premises. Haddad et al. ${ }^{21}$ in a recent literature review involving training load monitoring in individual and team sports, using the session rating of perceived exertion (RPE) method, confirmed the ecological validity, reliability, and usefulness of the method. Despite the results presented, the study has limitations such as the relatively small sample size, the lack of analysis of a physiological variable and the lack of a performance test that could better direct the effect of the application of training loads and the consequent recovery investigated.

\section{CONCLUSIONS}

It was concluded that the dynamics of the internal training load and recovery status of volleyball athletes during 19 weeks of training presented linear behavior over the period analyzed. The results presented positively demonstrate the training monitoring process carried out, since the team presented their best results in terms of Fatigue status and Energy Index at the most important point of the season, competitive period II. Moreover, the appropriateness of applying the training loads to the team's competition schedule brought about a positive recovery status throughout the season under analysis.

All authors declare no potential conflict of interest related to this article

AUTHORS' CONTRIBUTIONS: Each author made significant individual contributions to this manuscript. TAGH: writing of the article and critical review of its intellectual content; PHPL, GGM, JVF and TFT: writing of the article and substantial contribution in the conception of the work; BMD, JMV, HCT and RM: final approval of the version of the article and critical review of its intellectual content; MGBF: final approval of the version of the article, substantial contribution in the conception of the work and critical review of its intellectual content.

\section{REFERENCES}

1. Debien PB, Mancini M, Coimbra DR, de Freitas DG, Miranda R, Bara Filho MG. Monitoring training load, recovery, and performance of Brazilian professional volleyball players during a season. Int J Sports Physiol Perform. 2018;13(9):1182-9.

2. Horta TA, Coimbra DR, Miranda R, Werneck FZ, Bara Filho MG. Is the internal training load different between starters and nostarters volleyball players submitted to the same external load training? A case study. Rev Bras Cineantropom Desempenho Hum. 2017b;19(4):395-405.

3. Moreira A, Freitas CG, Nakamura FY, Aoki MS. Percepção de esforço da sessão e a tolerância ao estresse em jovens atletas de voleibol e basquetebol. Rev Bras Cineantropom Desempenho Hum. 2010;12(5):345-51.

4. Issurin VB. New horizons for the methodology and physiology of training periodization. Sports Med. 2010:40(3):189-206

5. Timoteo TF, Seixas MB, Falci MF, Debien PB, Miloski B, Miranda R, et al. Impact of consecutive games on workload, state of recovery and well-being of professional volleyball players. J Exerc Physiol Online. 2017;20(3):130-40.

6. Schwellnus M, Soligard T, Alonso JM, Bahr R, Clarsen B, Dijkstra HP, et al. How much is too much? (Part 2) International Olympic Committee consensus statement on load in sport and risk of illness. Br J Sports Med. 2016;50(17):1043-52.

7. Kellmann M. Preventing overtraining in athletes in high-intensity sports and stress/recovery monitoring Scand J Med Sci Sports. 2010;20(Suppl 2):95-102.

8. Foster C, Rodriguez-Marroyo JA, de Koning JJ. Monitoring training loads: the past, the present, and the future. Int J Sports Physiol Perform. 2017;12(Suppl 2):S22-8.

9. Foster C, Florhaug JA, Franklin J, Gottschall L, Hrovatin LA, Parker S, et al. A new approach to monitoring exercise training. J Strength Cond Res. 2001;15(1):109-15.

10. Horta TA, Bara filho MG, Coimbra DR, Miranda R, Werneck FZ. Training load, physical performance, biochemical markers, and psychological stress during a short preparatory period in Brazilian elite male volleyball players. J Strength Cond Res. 2017c

11. Horta TA, Bara filho MG, Miranda R, Coimbra DR, Werneck FZ. Influência dos saltos verticais na percepção da carga interna de treinamento no voleibol. Rev Bras Med Esporte. 2017a;23(5):403-6.

12. Freitas $\mathrm{VH}$, Miloski B, Bara filho MG. Monitoramento da carga interna de um período de treinamento em jogadores de voleibol. Rev Bras Educ Fis Esporte. 2015;29(1):5-12.

13. Freitas VH, Nakamura FY, Miloski B, Samulski D, Bara-Filho, MG. Sensitivity of physiological and psychological markers to training load intensification in volleyball players. J Sports Sci Med. 2014;13(3):571-9.

14. Bara Filho MG, Andrade FC, Nogueira RA, Nakamura FY. Comparação de diferentes métodos de controle da carga interna em jogadores de voleibol. Rev Bras Med Esporte. 2013;19(2):143-6.

15. Nakamura FY, Moreira A, Aoki MS. Training load monitoring: is the session rating of perceived exertion a reliable method? Rev Educ Fís/UEM. 2010;21(1):1-11

16. Kenttä G, Hassmén P. Overtraining and recovery. A conceptual model. Sports Med.1998;26(1):1-16

17. Rohlfs IC, Rotta TM, Luft CD, Andrade A, Krebs RJ, Carvalho T. A Escala de Humor de Brumel (Brums): instrumento para detecção precoce da síndrome do excesso de treinamento. Rev Bras Med Esporte. 2008;14(3):176-81.
18. Osiecki R, Rubio TB, Coelho RL, Novack LF, Conde JH, Alves CG, et al. The total quality recovery scale (TQR) as a proxy for determining athletes' recovery state after a professional soccer match. J Exerc Physiol Online. 2015;18(3):27-32.

19. Arruda AF, Moreira A, Nunes JA, Viveiros L, Rose Jr. D, Aoki MS. Monitoramento do nível de estresse de atletas da seleção brasileira de basquetebol feminino durante a preparação para a copa américa 2009. Rev Bras Med Esporte. 2013;19(1):44-7.

20. Bourdon PC, Cardinale M, Murray A, Gastin P, Kellmann M, Varley MC, et al. Monitoring athlete training loads: consensus statement. Int J Sports Physiol Perform. 2017;12(Suppl 2):S2161-70.

21. Haddad M, Stylianides G, Djaoui L, Dellal A, Chamari K. Session-RPE method for training load monitoring: validity, ecological usefulness, and influencing factors. Front Neurosci. 2017;11:612.

22. Kenttä G, Hassmén P, Raglin JS. Mood state monitoring of training and recovery in elite kayakers. Eur J Sport Sci. 2006;6(4):245-53.

23. Hopkins WG, Marshall SW, Batterham AM, Hanin J. Progressive statistics for studies in sports medicine and exercise science. Med Sci Sports Exerc. 2009;41(1):3-13.

24. Kelly VG, Coutts AJ. Planning and monitoring training loads during the competition phase in team sports. Strength Cond J. 2007;29(4):32-7.

25. Horta TA, Barra Filho M, Coimbra DR, Werneck FZ, Miranda R. Perfil da carga de treinamento no voleibol de alto rendimento: um estudo de caso. Rev Bras Cienc Esporte. 2018.

26. Manzi V, D'ottavio S, Impellizzeri FM, Chaouachi A, Chamari K, Castagna C. Profile of weekly training load in elite male professional basketball players. J Strength Cond Res. 2010;24(5):1399-406.

27. Lacerda RP, Duarte TS, Coimbra DR, Timoteo TF, Miranda R, Bara Filho MG, et al. Comportamento da recuperação de atletas profissionais de voleibol em semanas com jogos e sem jogos. Col Pesq Educ Fis. 2015;14(2):23-30.

28. Luiz JG, Massari LR, Debien PB, Duarte TS, Coimbra DR, Miranda R, et al. Monitoramento das cargas de treinamento e recuperação na pré-temporada do voleibol. Col Pesqui Educ Fís. 2015;14(2):75-82.

29. Fowler P, Duffield R, Waterson A, Vaile J. effects of regular away travel on training loads, recovery, and injury rates in professional Australian soccer players. Int J Sports Physiol Perform. 2015;10(5):546-52

30. Fullagar HH, Duffield R, Skorski S, Coutts AJ, Julian R, Meyer T. Sleep and recovery in team sport: current sleep-related issues facing professional team-sport athletes. Int J Sports Physiol Perform. 2015;10(8):950-7.

31. Nogueira FC, Miloski B, Bara Filho MG, Lourenço LM. Influência da presença ou da ausência de jogos nas percepções de fadiga de atletas profissionais de voleibol durante uma temporada competitiva. Rev Port Cien Desp. 2017;(2):152-60.

32. Borrensen J, Lambert MI. The quantification of training load, the training response and the effect on performance. Sports Med. 2009;39(9):779-95.

33. Aoki MS, Arruda AF, Freitas CG, Miloski B, Marcelino PR, Drago G, et al. Monitoring training loads, mood states and jump performance over two periodized training mesocycles in elite young volleyball players. Int J Sports Sci Coach. 2017;12(1):130-7. 